\title{
The Effectiveness against Traffic Violations with Electronic Traffic Law Enforcement (ETLE)
}

\author{
Yuliantoro*) and Achmad Sulchan**) \\ *) Indonesian National Police, Resort Kudus, E-mail: \\ yuliantoro.yuliantoro69@gmail.com \\ **) Faculty of Law Universitas Islam Sultan Agung
}

\begin{abstract}
.
This study aims to determine and analyze the effectiveness of law enforcement against traffic violations with Electronic Traffic Law Enforcement (ETLE) and to identify and analyze the obstacles in law enforcement against traffic violations with Electronic Traffic Law Enforcement (ETLE) and find out the solutions. This research is an empirical juridical research by combining legal materials (which are secondary data) with primary data obtained in the field. The results of this study indicate that the effectiveness of Electronic Traffic Law Enforcement (ETLE) is still less effective in its implementation, judging from the data on violations that are still occurring, which are increasing compared to before the implementation of the ETLE system. Public awareness of compliance in driving on the road is still lacking and tends to ignore traffic signs because there are no police officers on the road. The factor for the ineffectiveness of implementing Electronic Traffic Law Enforcement (ETLE) is the lack of camera equipment installed on every road and every traffic light so that there is a lack of valid data to detect traffic violators and also there are still many violators found on the highway, especially motorcycle riders who do not drive in an orderly manner in the absence of police officers on duty on the road.

Keywords: Effectiveness; Electronic; Enforcement; Law; Traffic; Violators.
\end{abstract}

\section{Introduction}

The state of Indonesia is a state of law, what is meant by a state of law is a state that upholds the rule of law to uphold truth and justice, and there is no power that cannot be accounted for (accountable). ${ }^{1}$ The law stipulates what to do and what not to do or not to do. The legal targets to be addressed are not only people who actually act against the law, but also legal actions that are likely to occur, and to state equipment to act according to the law. ${ }^{2}$ Such a system of working law applies one form of law enforcement in force in Indonesia. ${ }^{3}$

According to Lawrence M. Friedman, the legal system is a legal entity consisting of three elements, namely the legal structure, legal substance and legal culture. The structure is the framework or framework of the legal system, the part that survives, the part that gives a kind of shape and boundaries to the whole legal

\footnotetext{
${ }^{1}$ Elucidation of Article 1 Paragraph (3) of Constitution of the Republic of Indonesia 1945.

${ }^{2}$ Setiyanto, Gunarto and Sri Endah Wahyuningsih. (2017). Efektivitas Penerapan Sanksi Denda ETilang Bagi Pelanggar Lalu Lintas Berdasarkan Undang-Undang Nomor 22 Tahun 2009 Tentang Lalu Lintas Dan Angkutan Jalan (Studi Di Polres Rembang). Jurnal Hukum Khaira Ummah Vol. 12. No. 4 December, 2017: 742- 766, http://jurnal.unissula.ac.id/index.php/ihku/articl e/viewFile/2293/1721

${ }^{3}$ Evi Hartanti, 2000, Tindak Pidana Korupsi, first printing, second edition, Sinar Graphic, Jakarta, p. 1.
} 
building. The legal structure is manifested in the form of institutions or individuals implementing the agency's officers, such as the police, prosecutors, and courts.

Legal substance is the entirety of legal principles, legal norms and legal rules, both written and unwritten, including Court decisions in terms of the substance of criminal law in Indonesia, so our main material criminal legislation is the Criminal Code (KUHP), while the parent of formal criminal legislation (procedural law) is the Criminal Procedure Code (KUHAP).

The third element of the legal system is legal culture, namely the customs or culture of the community that accompanies law enforcement. The legal culture resides in the community as well as in law enforcement officers. Or it can also be said, that legal culture is the entire fabric of social values related to the law along with attitudes that affect the law, such as shame, guilt when breaking the law and so on. ${ }^{4}$

Police officers who are part of the legal structure carry out law enforcement activities to maintain traffic security and order in accordance with the Act No. 22 of 2009 concerning Road Traffic and Transportation. The information system for every violation by motorists on the highway must be the basis for taking action against violations in the next stage, meaning that information on violations that have been committed by each person must always be identified by all police officers who have ticketed. ${ }^{\text {IIt }}$ is no longer a public secret, if in practice bribes often occur in traffic operations. So that is the reason that can be used as the basis by the Indonesian National Police to start implementing a new system called the E-ticket system.

This E-ticket system can be trusted to reduce the practice of illegal levies or called extortion. The e-ticket system itself was enforced on December 6, 2017. The basis of the E-ticket itself is in the form of regulations in Act No. 22 of 2009 concerning Road Traffic and Transportation and Government Regulation Number 80 of 2012 concerning Procedures for Inspection of Motorized Vehicles on the Road and Enforcement of Traffic and Road Transportation Violations as well as in Act No. 11 of 2008 concerning Electronic Transactions.

Electronic Traffic Law Enforcement(hereinafter written ETLE), is a traffic law enforcement system based on information technology using electronic devices in the form of cameras that can detect traffic violations and motorized vehicle data automatically (Automatic Number Plate Recognition). And ETLE cameras can be used as evidence in traffic violations cases. ${ }^{6}$

ETLE is an effort to implement technology to record violations in traffic electronically to support security, safety and order. The purpose of implementing

\footnotetext{
${ }^{4}$ Satjipto Rahardjo, 1986, Pembangunan Hukum dalam Perspektif Politik, Hukum Nasional, CV. Rajawali, Jakarta, p. 27.

5 Rahardian IB, Dian AK, 2011, Program Aplikasi Berbasis Wap Untuk Meningkatkan Akuntabilitas Sistem Tilang Pelanggaran Tata Tertib Lalu Lintas Di Wilayah Polres Majalengka, Jurnal ICT-STMIK IKMI Vol 1 No. 1 July 2011 issue, p. 43.

${ }^{6}$ Korlantas Polri, "Akselerasi Progam 100 Hari Kapolri Bidang Lalu Lintas melalui Electronic Traffic Law Enforcement (ETLE) Presisi 2021" (Exposure of the Head of the Police Headquarters Inspector General Pol. Drs. Istiono, MH).
} 
ETLE is to minimize parties who commit extortion when taking action against traffic violations. Not only that, the application is to improve driving discipline. ${ }^{7}$

Obstacles in ETLE enforcement are found in infrastructure, community, and cultural factors. The infrastructure factor in the implementation of ETLE requires sophisticated tools in the form of ticket cameras and mobile ticketing cameras as well as other sophisticated tools to support ETLE enforcement in large numbers, this of course requires very large funds, because the jurisdiction of the Kudus Resort Police has an area which is quite wide.

The next important factor is the cultural factor, with the existence of a new system such as the implementation of ETLE, it is not necessarily the community that understands and understands what ETLE actually is. The Indonesian National Police, through mass and electronic media, have frequently disseminated the implementation of the ETLE system with the aim of preventing the practice of bribery and peace price bargaining by traffic violators against police officers. ${ }^{8}$

The culture of the people who tend to be obedient and obedient will drive on the highway if there are officers on guard, if you see on the highway there are no police officers on guard, car drivers and especially motorbikes often commit violations, both those who do not wear driving equipment such as helmets and also violate traffic signs. ${ }^{9}$ It is feared that traffic violations will increase if there are no police officers assigned to the road to supervise.

The Kudus Resort Police Traffic Unit noted that 3,241 motorists were caught on CCTV (closed circuit television) committing traffic violations since the Electronic Traffic Law Enforcement (ETLE) system was implemented. "That many violations are the result of our records from March 23, 2021 until this week," said Head of the Kudus Police Traffic Unit AKP Galuh Pandu Pandega in Kudus. ${ }^{10}$

\section{Research Methods}

The approach method in this research is a sociological juridical approach. The research specifications used by researchers in discussing the problem are descriptively analytical, data obtained from observations, interviews, documents and field notes and data collection methods sourced from primary and secondary data, while the data analysis method uses qualitative juridical methods.

\section{Results and Discussion}

\subsection{Law Enforcement Against Traffic Violations With Electronic Traffic Law Enforcement (ETLE)}

The definition of law enforcement can also be interpreted as the implementation of law by law enforcement officers and by everyone who has an

\footnotetext{
7 “Penerapan ETLE Berlaku Secara Nasional”, Media Indonesia, 28 March 2021, p. 7.

${ }^{8}$ Setiyanto, Op.cit

9 Octaviani, Ice. 2019. "Kepatuhan Pengendara Sepeda Motor Menyalakan Lampu Di Siang Hari Di Kota Bengkulu Ditinjau Dari Hukum Islam." Scription, Constitutional Law Faculty of Sharia IAIN Bengkulu, p. 21.

10 https://www.voice.com/otomotif/2021/04/01/234500/pepembegar-etle-terbanyak-di-kudussaat-ini-tak-gunakan-helm
} 
interest in accordance with their respective authorities according to the applicable legal rules. The enforcement of criminal law is an integral part of the process, beginning with the investigation, arrest, detention, trial of the accused and ending with the prison of the convict. ${ }^{11}$

Traffic violations are certain violations of laws and regulations in the field of traffic and road transportation which are detected automatically by Electronic Traffic Law Enforcement (ETLE) devices and systems. Violation is "overtredingen" or violation means an act that violates something and is related to the law, means nothing but an act against the law. ${ }^{12}$

A traffic violation is an act or action taken by a person driving a public vehicle or motorized vehicle as well as a pedestrian which is contrary to the applicable traffic laws and regulations. Regulations on road traffic and transportation in Indonesia are nationally regulated in the Act No. 22 of 2009 concerning Road Traffic and Transportation. This law is the basis and guideline in the prosecution of traffic violations.

Electronic Traffic Law Enforcement (ETLE), is a traffic law enforcement system based on information technology using electronic devices in the form of cameras that can detect traffic violations and motorized vehicle data automatically (Automatic Number Plate Recognition). And ETLE cameras can be used as evidence in traffic violations cases. ${ }^{13}$

According to the results of an interview with Kanit Gakum, the Kudus Resort Police said that the implementation of the ETLE system aims to provide information about traffic violations digitally so that the public will easily access the types of violations that are applied to violators. The existence of ETLE can also support the accountability of the police who are authorized to handle traffic rules violations. All traffic violations will be recorded rigidly by the system from input to output, so that no data on handling violations are missed and their handling is transparent. ${ }^{14}$

The Head of the Gakum of the Kudus Resort Police, IPDA Firman Abit Prasetya, added that the results of the ETLE camera recordings could be used as evidence in cases of traffic violations.

Law enforcement carried out by the ETLE system is a traffic violation recorded by CCTV that has been installed in the area of traffic signs, then the data is verified by the ETLE Back Office, in this case a Police officer. Data verification is complete, then a traffic violation confirmation letter is made along with a photo of the violator and then sent to the violator's address through PT. Indonesian post.

For violators who have received the ETLE confirmation letter, they will be given 14 days to confirm to the ETLE service room, while those who do not confirm the STNK will be immediately blocked. Violators who confirm will receive a ticket and can then pay a fine to Bank BRI or join a trial in court.

\footnotetext{
${ }^{11}$ Harun M.Husen, 1990, Kejahatan dan Penegakan Hukum Di Indonesia, Rineka Cipta, p. 58.

${ }^{12}$ Wirjono Prodjodikoro, 2003. Asas-asas Hukum Pidana. Bandung: Refika Aditama, p. 33

${ }^{13}$ Korlantas Polri, Op.Cit.

${ }^{14}$ Interview with IPDA Head of Gakum, Firman Abit Prasetya, S.Tr.K.
} 


\subsection{Effectiveness of Law Enforcement Against Traffic Violations With Electronic Traffic Law Enforcement (ETLE)}

Effectiveness means the effectiveness of the effect of success or efficacy or efficacy. Talking about the effectiveness of the law certainly cannot be separated from analyzing the characteristics of the two related variables, namely the characteristics or dimensions of the target object used. ${ }^{15}$

The theory of legal effectiveness according to Soerjono Soekanto is that the effectiveness of a law is determined by five factors, namely: 16

- The legal factor itself (statutory regulations);

- Law enforcement factors, namely the parties that form and apply the law;

- Factors of facilities or facilities that support law enforcement;

- Community factors, namely the environment in which the law applies or is applied;

- Cultural factors, namely as a result of work, creativity and taste based on human initiative in social life

The degree of legal effectiveness, according to Soerjono Soekanto, is determined by the level of community compliance with the law, including law enforcers, so that the assumption is known that a high level of compliance is an indicator of the functioning of a legal system. The functioning of the law is a sign that the law is achieving its legal objectives, namely trying to maintain and protect the community in social life. ${ }^{17}$

According to the results of an interview with the Head of Traffic of the Kudus Resort Police AKP Galuh Pandu PF revealed that the effectiveness of law enforcement against traffic violators with the ETLE system in the jurisdiction of the Kudus Resort Police has not been effective due to two factors, namely internal and external factors: 18

- Internal Factor

Internal factors in the implementation of the ETLE system are the lack of facilities and infrastructure, including CCTV cameras are not installed at all traffic sign light points and also in places prone to traffic violations, so that violations that occur are not all validly detected.

- External Factors

The external factor is the lack of public knowledge about the procedures for the ETLE system and also the lack of public awareness of being obedient and obedient in driving on the highway when there are no police officers.

\section{Clossing}

The implementation of ETLE by the Police has a good purpose because there is transparency in its action but implementation in the field is still not effective because there is still a lack of advice that supports the implementation of this ETLE

\footnotetext{
15 Barda Nawawi Arief, 2013, Kapita Selekta Hukum Pidana, Bandung: Citra Aditya, p. 67.

16 Soerjono Soekanto, 2008, Faktor-Faktor yang Mempengaruhi Penegakan Hukum, Jakarta: PT. Raja Grafindo Persada, p. 8.

17 Soerjono Soekanto, 2007, Efektivitas Hukum dan Peranan Saksi, Remaja Karya Bandung, p.7.

18 Interview with Head of Traffic AKP Galuh Pandu PF, SH, SIK, MH
} 
system and there are also many people who do not have awareness in obeying traffic signs because they do not the presence of officers on guard, this can be seen from the increase in traffic violations. ETLE has many advantages, but it also has drawbacks in the implementation of ETLE for that it is necessary to improve and add facilities and infrastructure and also need to increase the socialization of the ETLE mechanism to the community so that they can feel the benefits.

\section{References}

\section{Journals}

[1] Rahardian IB, Dian AK, 2011, Program Aplikasi Berbasis Wap Untuk Meningkatkan Akuntabilitas Sistem Tilang Pelanggaran Tata Tertib Lalu Lintas Di Wilayah Polres Majalengka, Jurnal ICT-STMIK IKMI Vol 1 No. 1 Edition July 2011, p. 43.

[2] Setiyanto, 2017, Efektifitas Penerapan Sanksi Denda E-tilang Bagi Pelanggar Lalu Lintas Berdasarkan Undang-Undang Nomor 22 Tahun 2009 Tentang Lalu Lintas dan Angkutan Jalan (Studi di Polres Rembang), Jurnal Hukum Khaira Ummah Vol. $12 . \quad$ No. 4 December 2017, http://jurnal.unissula.ac.id/index.php/jhku/articl e/viewFile/2293/1721

[3] Ong Argo Victoria, Ade Riusma Ariyana. 2020. POLICY ANALYSIS STUDY OF THE TRAFFIC ACCIDENT OF CRIMINAL SYSTEM WHICH MAKE LOSS OF LIFE, International Journal of Law Reconstruction, Vol. 4 No. 2, p. 136-144, http://jurnal.unissula.ac.id/index.php/lawreconstruction/article/view/1138 $\underline{2}$

\section{Books}

[1] Bahder Johan Nasution, 2009, Metode Penelitian Ilmu Hukum, CV. Mandar Maji, Bandung.

[2] Barda Nawawi Arief, 2013, Kapita Selekta Hukum Pidana, Citra Aditya, Bandung.

[3] Evi Hartanti, 2000, Tindak Pidana Korupsi, First Printing, Second Edition, Sinar Grafika, Jakarta.

[4] Harun M.Husen, 1990, Kejahatan dan Penegakan Hukum Di Indonesia, Rineka Cipta, Jakarta.

[5] Marcus Priyo Gunarto, 2011, Kriminalisasi dan Penalisasi Dalam Rangka Fungsionalisasi Perda dan Retribusi, Program Doktor Ilmu Hukum Universitas Diponegoro Semarang.

[6] Moeljatno, 1993, Asas-asas Hukum Pidana, Putra Harsa, Surabaya.

[7] Octaviani, Ice. 2019. "Kepatuhan Pengendara Sepeda Motor Menyalakan Lampu Di Siang Hari Di Kota Bengkulu Ditinjau Dari Hukum Islam." Scription, Hukum Tata Negara Fakultas Syariah IAIN Bengkulu.

[8] Ronny Hanitijo Soemitro, 1985, Metodologi Penulisan Hukum. Ghalia Indonesia, Jakarta.

[9] Salim,H.S dan Erlis Septiana Nurbani, 2013, Penerapan Teori Hukum Pada Tesis dan Disertasi, Edsis Pertama, ctk Kesatu, Rajawali Press, Jakarta.

[10] Satjipto Rahardjo, 1986, Pembangunan Hukum dalam Perspektif Politik, Hukum Nasional, CV. Rajawali, Jakarta. 
[11] Soerjono Soekanto, 1983, Faktor-faktor Yang Mempengaruhi Penegakan Hukum, UI Pres, Jakarta.

[12] Soerjono Soekanto, 2007, Efektivitas Hukum dan Peranan Saksi, Remaja Karya Bandung.

[13] Wirjono Prodjodikoro, 2003, Asas-asas Hukum Pidana., Refika Aditama, Bandung.

[14] Zainudin Ali, 2014, Metode Penelitian Hukum, Sinar Grafika, Jakarta.

\section{Regulation}

[1] Constitution of the Republic of Indonesia 1945

[2] Act No. 2 of 2002 concerning the Indonesian National Police;

[3] Act No. 11 of 2008 concerning information and electronic transactions;

[4] Act No. 22 of 2009 concerning Road Traffic and Transportation;

[5] Government Regulation No. 8 of 2012 concerning procedures for inspection of motorized vehicles on the road and prosecution for violations of Traffic and Road Transportation;

[6] Regulation of the Chief of Police of the Republic of Indonesia Number 5 of 2012 concerning registration and identification of motorized vehicles;

\section{Internet}

[1] Klikpositive, "Observer Reveals Challenges and Problems That Will Happen In Electronic Ticketing System" accessed from https://klikpositive.com/, accessed on March 31, 2021.

[2] https://www.voice.com/otomotif/2021/04/01/234500/pejuang-etleterbanyak-di-kudus-saat-ini-tak-gunakan-helm. 